\title{
Mesenchymal stem cell 3D encapsulation technologies for biomimetic microenvironment in tissue regeneration
}

\author{
Hyerim Kim ${ }^{1 \dagger}$, Chaewon Bae ${ }^{1 \dagger}$, Yun-Min Kook ${ }^{2}$, Won-Gun Koh ${ }^{2}$, Kangwon Lee ${ }^{1,3^{*}}$ and Min Hee Park ${ }^{1,4^{*}}$
}

\begin{abstract}
Mesenchymal stem cell (MSC) encapsulation technique has long been emerged in tissue engineering as it plays an important role in implantation of stem cells to regenerate a damaged tissue. MSC encapsulation provides a mimic of a three-dimensional (3D) in vivo environment to maintain cell viability and to induce the stem cell differentiation which regulates MSC fate into multi-lineages. Moreover, the 3D matrix surrounding MSCs protects them from the human innate immune system and allows the diffusion of biomolecules such as oxygen, cytokines, and growth factors. Therefore, many technologies are being developed to create MSC encapsulation platforms with diverse materials, shapes, and sizes. The conditions of the platform are determined by the targeted tissue and translation method. This review introduces several details of MSC encapsulation technologies such as micromolding, electrostatic droplet extrusion, microfluidics, and bioprinting and their application for tissue regeneration. Lastly, some of the challenges and future direction of MSC encapsulation technologies as a cell therapy-based tissue regeneration method will be discussed.
\end{abstract}

Keywords: Mesenchymal stem cells, 3D encapsulation, Advanced technologies, Hydrogel, Tissue regeneration

\section{Background}

To treat tissue and organ injuries, cell-based therapy through the transplantation of stem cells into the damaged site to generate new tissue has been the novel approach for tissue regeneration. Among the various types of stem cells, mesenchymal stem cells (MSCs) are commonly used for cell therapy because of many advantages, such as their capacity for self-renewal and differentiation into multi-lineages without ethical issue. Moreover, they have a low risk of teratoma development and low immunogenicity $[1,2]$. MSCs can be derived from many types of tissues, for example, the bone marrow, adipose tissue, umbilical cord blood, placenta, lung, liver, and skin [3, 4]. Thus, MSCs have been observed to differentiate into many types of tissue including bone, cartilage, muscle, fat, tendon, ligament, and other connective tissues [5]. Moreover, MSCs secrete various cytokines and

\footnotetext{
*Correspondence: kangwonlee@snu.ac.kr; minheepark@kicet.re.kr ${ }^{+}$Hyerim Kim and Chaewon Bae contributed equally to this work. ${ }^{1}$ Program in Nanoscience and Technology, Graduate School of Convergence Science and Technology, Seoul National University, Seoul, Republic of Korea Full list of author information is available at the end of the article
}

growth factors such as interleukin-2 (IL-2), interleukin-8 (IL-8), monocyte chemotactic protein-1 (MCP-1), stromal-derived factor-1 (SDF-1), vascular endothelial growth factor (VEGF), and transforming growth factor-beta (TGF- $\beta$ ) which regulate the immune system as well as many intercellular signaling pathways $[6,7]$. These secreted bioactive molecules stimulate organotypic cells, enhancing their activities, and reduce fibrosis and apoptosis [8]. Therefore, MSCs are not only capable of differentiation, but also of affecting various reactions and signaling pathways in the human body.

To deliver MSCs and maintain their advantages (i.e., their capacity for viability and differentiation) in damaged tissues, it is essential to mimic the in vivo microenvironment through three-dimensional (3D) construction and as such retain the cell's various effects under the 3D environment, such as their phenotype, adhesion, metabolism, and response signal to soluble factors [9]. In fact, cells show different physiological and morphological results in two-dimensional (2D) and 3D environments [10]. In particular, MSCs have better osteogenic [11], adipogenic [12], and hepatic $[13,14]$ differentiation behavior in the $3 \mathrm{D}$ 
environment. Moreover, MSCs show improved differentiation when they are co-cultured with other types of cells such as human umbilical vein endothelial cells (HUVECs) [15], osteoblasts [16], and hematopoietic stem/progenitor cells (HSPCs) [17] compared with those cultured alone in the 3D environment. This is because MSCs interact with other cells differently in the 3D environment compare with the 2D monolayer environment, which enhances the co-culture effect and results in increased cell expansion and tissue regeneration.

The encapsulation of MSCs, by entrapping the viable cells in a 3D semi-permeable hydrogel matrix, is one of the simple methods to introduce a 3D environment. The cell encapsulation is accomplished through the solidification of a cell-suspended liquid material [18]. The 3D cell-encapsulating matrix should safely deliver the MSCs and maintain their viability and function in vitro and in vivo to ultimately have therapeutic potential. Successfully encapsulated MSCs can then differentiate into the targeted lineages, for example, tendon [19], intervertebral disk [20], bone [21], and articular cartilage [22]. Accordingly, the encapsulation of MSCs into a 3D matrix is a very efficient and effective method in tissue regeneration, and many 3D encapsulation technologies have been developed as powerful tools for regenerative medicine. A variety of cell encapsulation technologies can produce 3D matrices of various shapes and sizes, which affect the viability and differentiation of MSCs. For effective tissue regeneration, the shape and size of the 3D matrix must be determined selectively, depending on the property of the target tissue and the materials used (Table 1). Therefore, it is crucial to understand the principles and processes of the various MSC encapsulation technologies in order to select the most efficient and effective one for the intended purpose.

In this review, we discuss the various MSC encapsulation technologies, from the old methods to the recently developed ones. We also describe several applicable tissue regeneration strategies with the introduced encapsulation technologies. Finally, the challenges of MSC encapsulation and its future direction for tissue regeneration will be presented.

\section{MSC encapsulation technology}

To overcome the 2D environment, the first attempt of a $3 \mathrm{D}$ network for cells was the hanging drop tissue culture system developed by Ross Harrison in 1906 [23]. However, the first introduction of cell encapsulation occurred in the 1960s, when Chang proposed the development of semipermeable microcapsules using nylon membranes by an emulsification method in 1964 [24]. In other studies, using emulsification methods, collagen-agarose [25] and peptides [26] were introduced as the 3D microenvironment for cells. After the early successful strategy by
Chang, cell encapsulation within beads and matrices was studied extensively. One of the most common methods for cell encapsulation is entrapment of cells within hydrogel beads which is a very convenient technique that is still being used at present because of its simplicity and stable formation. It was easily achieved by dropping the alginate hydrogel from a syringe into a calcium chloride solution [27]. Aside from the alginate material, this method was also applied to fabricate various cell encapsulation membranes through ionic crosslink formation [28-30]. In addition, processes such as coaxial air jet application and the liquid jet method were developed for cell-entrapped droplet formation. Other developed methods including the macromolecular collagen type I matrix [31], hollow fibers produced by injection and co-extrusion [32], and photopolymerization by UV to reduce cell death without organic solvent were developed. Among these preliminary methods, some technologies are still being used in the same or better way to this day. The widespread and newly developed cell encapsulation technologies, including micromolding, electrostatic droplet extrusion, microfluidics, and bioprinting have been studied since 1958. Recently, microfluidics and bioprinting are widely applied for cell encapsulation. Also, 4D printing technology in which biomaterials or cells are responsive to external stimuli has been developed [33]. With the increasing interest in MSCs, many research groups have started to encapsulate MSCs for cell-based therapy (Fig. 1). Therefore, in this section, we will review the principles behind these technologies with a focus on MSC encapsulation.

\section{Micromolding method}

The micromolding method was used to fabricate the cell-laden constructs on a massive scale using specialized lithography equipment. For cell encapsulation, micromolding is a powerful tool that regulates the cellular microenvironment while encapsulating MSCs using specialized lithography equipment (Fig. 2a). Micromolding is the proper technology to manufacture a uniform capsule with excellent reproducibility, which is the reason for its extensive use. There are several types of micromolding methods, including replica, capillary, imprinting, and microtransfer molding. Among these methods, replica molding and capillary molding are easy to manufacture and have excellent repeatability at low cost, so they are currently widely used.

Replica molding is a process in which structures of various shapes and sizes are fabricated by diverse types of molds, using the gelation of a precursor polymer [34]. Polydimethylsiloxane (PDMS) membranes are the most commonly used templates for the gel structures. The polymer solution is poured onto a master made of a silicon substrate and microstructure, and the cured PDMS 
Table 1 Summary of encapsulation technologies with diverse materials and MSC types for different target tissues

\begin{tabular}{|c|c|c|c|c|c|c|}
\hline Technologies & & Benefits and limitations & Materials & MSC type & Target tissue & Reference \\
\hline \multirow{3}{*}{\multicolumn{2}{|c|}{ Micromolding }} & \multirow{3}{*}{$\begin{array}{l}\text { Benefits: } \\
\text { - Controlled shape } \\
\text { - Controlled size } \\
\text { Limitations: } \\
\text { - Batch process }\end{array}$} & Fibrin & $\begin{array}{l}\text { Human bone marrow- } \\
\text { derived stem cell }\end{array}$ & Blood vessel & {$[36]$} \\
\hline & & & Alginate & $\begin{array}{l}\text { Bone marrow-derived } \\
\text { stem cell }\end{array}$ & Non-specific & {$[37]$} \\
\hline & & & $\begin{array}{l}\text { Polyethylene glycol } \\
\text { (PEG)-based hydrogel }\end{array}$ & $\begin{array}{l}\text { Human mesenchymal } \\
\text { stem cells }\end{array}$ & Non-specific & {$[38]$} \\
\hline \multirow{3}{*}{\multicolumn{2}{|c|}{$\begin{array}{l}\text { Electrostatic } \\
\text { droplet extrusion }\end{array}$}} & \multirow{3}{*}{$\begin{array}{l}\text { Benefits: } \\
\text { - Controlled droplet size } \\
\text { - Uniform droplet size } \\
\text { Limitations: } \\
\text { - Materials constraints }\end{array}$} & Alginate & $\begin{array}{l}\text { Rat adipose-derived } \\
\text { stem cell }\end{array}$ & Non-specific & {$[50]$} \\
\hline & & & Alginate & $\begin{array}{l}\text { Human adipose-derived } \\
\text { stem cell }\end{array}$ & Non-specific & {$[51]$} \\
\hline & & & Alginate-lyase & $\begin{array}{l}\text { Rat adipose-derived } \\
\text { stem cell }\end{array}$ & Bone & {$[85]$} \\
\hline \multirow[t]{5}{*}{ Microfluidics } & \multirow[t]{4}{*}{ Droplet } & \multirow{4}{*}{$\begin{array}{l}\text { Benefits: } \\
\text { - Controlled monodispersity } \\
\text { - Controlled dimensions and shape } \\
\text { Limitations: } \\
\text { - Non-scalable }\end{array}$} & $\begin{array}{l}\text { Gelatin norbornene } \\
\text { (GelNB) and PEG }\end{array}$ & $\begin{array}{l}\text { Human bone marrow- } \\
\text { derived stem cell }\end{array}$ & $\begin{array}{l}\text { Hyaline } \\
\text { cartilage }\end{array}$ & {$[60]$} \\
\hline & & & $\begin{array}{l}\text { Gelatin methacryloyl } \\
\text { (GelMA) }\end{array}$ & $\begin{array}{l}\text { Rat bone marrow- } \\
\text { derived stem cell }\end{array}$ & Bone & {$[61]$} \\
\hline & & & $\begin{array}{l}\text { Alginate/RGD- } \\
\text { alginate }\end{array}$ & $\begin{array}{l}\text { Human bone marrow- } \\
\text { derived stem cell }\end{array}$ & Bone & {$[87]$} \\
\hline & & & RGD-alginate & $\begin{array}{l}\text { Human periodontal } \\
\text { ligament stem cell/ } \\
\text { gingival mesenchymal } \\
\text { stem cell }\end{array}$ & Cartilage & {$[84]$} \\
\hline & Microfiber & $\begin{array}{l}\text { Benefits: } \\
\text { • Homogeneous } \\
\text { • Continuous } \\
\text { Limitations: } \\
\text { - Flow friction } \\
\text { - Clogging in microchannels }\end{array}$ & Alginate & $\begin{array}{l}\text { Mouse bone marrow- } \\
\text { derived stem cell }\end{array}$ & Blood vessel & {$[65]$} \\
\hline \multirow[t]{10}{*}{ Bioprinting } & \multirow[t]{4}{*}{$\begin{array}{l}\text { Inkjet } \\
\text { bioprinting }\end{array}$} & \multirow{4}{*}{$\begin{array}{l}\text { Benefits: } \\
\text { • Low cost } \\
\text { • High-throughput } \\
\text { Limitations: } \\
\text { - Nozzle clogging } \\
\text { - Non-uniform droplet size }\end{array}$} & PEG-GelMA & $\begin{array}{l}\text { Human bone marrow- } \\
\text { derived stem cell }\end{array}$ & Cartilage/bone & {$[69]$} \\
\hline & & & $\begin{array}{l}\text { Type I collagen- and } \\
\text { chitosan-agarose } \\
\text { blends }\end{array}$ & $\begin{array}{l}\text { Human bone marrow- } \\
\text { derived stem cell }\end{array}$ & Adipose/bone & [70] \\
\hline & & & Fibrin-collagen & $\begin{array}{l}\text { Human amniotic fluid- } \\
\text { derived stem cell and } \\
\text { bone marrow-derived } \\
\text { stem cell }\end{array}$ & Skin & {$[90]$} \\
\hline & & & Agarose-collagen & $\begin{array}{l}\text { Human bone marrow- } \\
\text { derived stem cell }\end{array}$ & Bone & {$[86]$} \\
\hline & \multirow[t]{4}{*}{$\begin{array}{l}\text { Extrusion } \\
\text { bioprinting }\end{array}$} & \multirow{4}{*}{$\begin{array}{l}\text { Benefits: } \\
\text { • High cell density } \\
\text { - Wide range of viscous materials } \\
\text { Limitations: } \\
\text { - Slow speed } \\
\text { - Viscous liquid only }\end{array}$} & $\begin{array}{l}\text { Methacrylamide } \\
\text { gelatin }\end{array}$ & $\begin{array}{l}\text { Rat bone marrow- } \\
\text { derived stem cell }\end{array}$ & Bone & [73] \\
\hline & & & $\begin{array}{l}\text { Polylactic acid (PLA)/ } \\
\text { GelMA }\end{array}$ & $\begin{array}{l}\text { Rat bone marrow- } \\
\text { derived stem cell }\end{array}$ & Bone & [74] \\
\hline & & & $\begin{array}{l}\text { Cellulose and } \\
\text { alginate }\end{array}$ & $\begin{array}{l}\text { Human bone marrow- } \\
\text { derived stem cell }\end{array}$ & Cartilage & {$[83]$} \\
\hline & & & Skin-derived ECM & $\begin{array}{l}\text { Human adipose- } \\
\text { derived mesenchymal } \\
\text { stem cell }\end{array}$ & Skin & {$[89]$} \\
\hline & \multirow[t]{2}{*}{$\begin{array}{l}\text { Laser-assisted } \\
\text { bioprinting }\end{array}$} & \multirow{2}{*}{$\begin{array}{l}\text { Benefits: } \\
\text { • High cell viability } \\
\text { - Various bioink available } \\
\text { Limitations: } \\
\text { • High cost }\end{array}$} & $\begin{array}{l}\text { Polyester urethane } \\
\text { urea (PEUU) }\end{array}$ & $\begin{array}{l}\text { Human bone marrow- } \\
\text { derived } \\
\text { stem cell }\end{array}$ & Cardiac & {$[79]$} \\
\hline & & & Plasma-alginate & $\begin{array}{l}\text { Porcine bone marrow- } \\
\text { derived stem cell }\end{array}$ & Cartilage/bone & {$[80]$} \\
\hline
\end{tabular}




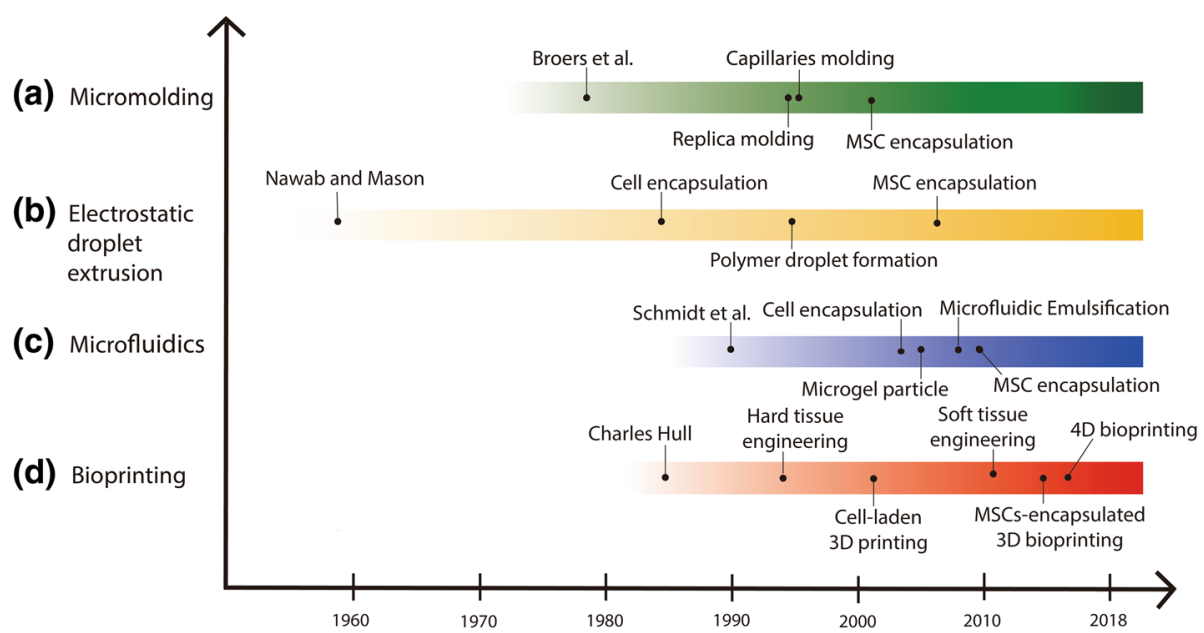

Fig. 1 Technical history and principal description of the technologies developed to achieve cell encapsulation, by year. a Micromolding was used in a variety of fields, but not for cell encapsulation until the early 1980s. Lithography based on micromolding was founded by Broers et al. [92] whereas techniques using replica [93] and capillary molding [94] were developed in 1996, and MSC encapsulation began in 2002. b Nawab and Mason suggested liquid droplets under electrostatic fields, which formed the principle of electrostatic droplet extrusion in 1958 [95]. For cell encapsulation using this technology, Goosen et al. proposed cell immobilization within a semipermeable membrane [96]. Moreover, Bugarski et al. proved the mechanism of polymer droplet formation with electrostatic droplet extrusion in 1994 [42]. Finally, MSC encapsulation was conducted in the late 2000s [97, 98]. c Schmidt et al. introduced a microfluidic device in 1990 [99], and the cell encapsulation was studied by Sugiura in 2005 [100]. Zhang et al. generated microgel particles with a capsular structure [101]. Microfluidic emulsification, achieved by Edd et al., offered enhanced controls over a number of encapsulated cells [102]. In 2010, MSC encapsulation was beginning to be studied. $\mathbf{d}$ The 3D printer was invented by Charles W. Hull in 1983 [103]. The inkjet 3D printing-based hard tissue scaffold was developed by Gima et al. in the early 1990s [104], which was an earlier step for application into soft tissue engineering [105]. Cell-laden and MSC-encapsulated 3D bioprinting was attempted form the 2000s onward after the development of the cell-free printed scaffold [74]. Finally, 4D bioprinting was developed as an advanced bioprinting technique for next-generation technology in the biomedical fields [106]

(a)

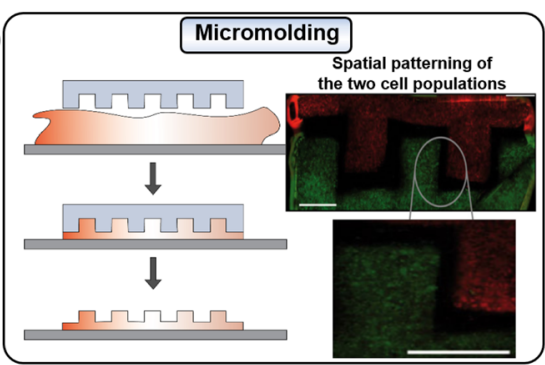

(c)

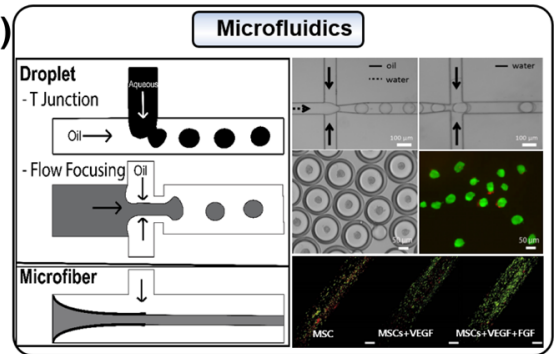

(b)

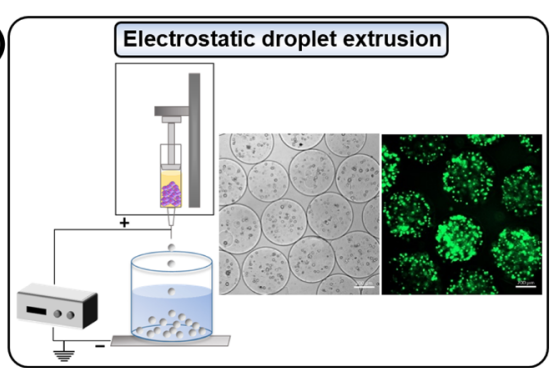

(d)

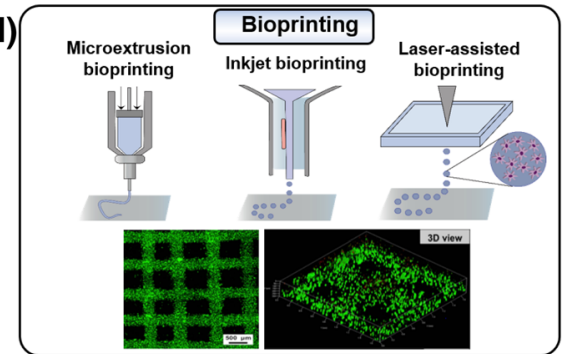

Fig. 2 MSC encapsulation technologies. The techniques for encapsulation of MSCs to maintain their viability, proliferation, and differentiation function to deliver the cells into damaged tissues in a 3D microenvironment are achieved through a micromolding (reproduced with permission from Reference [38]. Copyright 2013 John Wiley and Sons), b electrostatic droplet extrusion, c microfluidics (reproduced with permission from Reference [87]. Copyright 2013 Springer Nature and reproduced with permission from Reference [65]. Copyright 2017 IOP Publishing), and d bioprinting (reproduced with permission from Reference [107]. Copyright 2018 IOP Publishing) technologies. These technologies create various types of cell encapsulation platforms (e.g., microbeads, bulk matrices, and fiber) and specific shapes 
is then peeled off from the master [35]. To encapsulate cells with molding, the membrane is immersed in a cell-suspended polymer solution and then removed after solidification of the solution. Trkov et al. studied the vasculogenic potential of MSCs through replica molding microfabrication [36]. Vorwald et al. claimed that proper biomaterials should be considered as the molding resource for MSC transplantations; for example, the alginate hydrogel effectively encapsulates MSCs as spheroids [37]. Hamilton et al. designed and implemented a hydrogel replica molding, which successfully cultivated two or more cell types in a highly customized environment that represented the 3D tissue physiology [38]. They have developed a $3 \mathrm{D}$ hydrogel co-culture system by separating and isolating different cell populations using enzyme-sensitive glues. This platform enabled co-culture effects and cultivation to test the persistence of paracrine signals and provided great potential for the future study of various basic cell signals.

Micromolding in a capillary is a convenient technique for producing a patterned microstructure of an organic polymer on the surface of a solid substrate. This technology is achieved by flowing a polymer solution (e.g., PDMS fluids) to a prepared capillary patterned mold, whereupon the PDMS adheres tightly to a flat substrate and hardened to create a capillary channel. Then, cell-containing polymer solution is placed at the ends of channels to create cell encapsulating microtube and filled automatically into microchannel by capillary force. The resultant PDMS microchannel creates a partial vacuum inside the cavity and plays a role in attracting the polymer solution [39-41].

\section{Electrostatic droplet extrusion}

As an advanced facile technology relative to the simple syringe extrusion method, the electrostatic droplet extrusion method has been widely studied for MSC microencapsulation (Fig. 2b). Compared with other extrusion techniques such as air jet extrusion and vibrational encapsulation, electrostatic droplet extrusion provides manufactures with smaller beads with a diameter of less than $50 \mu \mathrm{m}$ [42]. Moreover, the advantage of this technology is that it can be performed under less stressful conditions without the use of organic solvents that reduce cell viability [43]. Even though a high electronic field is loaded for the process, the electrical potential does not affect cell viability because the main principle of electrostatic droplet extrusion is the disruption of a liquid jet by electrostatic forces. In this process, liquid is extruded through a needle connected to the high-voltage generator. Upon application of a potential to the needle, the liquid surface is transformed into a Taylor cone-like droplet, and the liquid cone expands to create a thin strand. At the end of the electrostatic droplet extrusion steps, small polymer droplets are formed by detaching from the aperture of the needle [44]. Furthermore, several factors can affect the size of the droplets, such as the electrostatic potential, the distance between the collecting device and syringe pump, the diameter of the needles, the flow rate, the type of polymer solution used, and the concentrations and viscosity of the solution [45].

As already mentioned above, the biopolymer alginate has been commonly used for cell encapsulation by electrostatic droplet extrusion because of its fast gelation process based on the ionic crosslinking mechanism. To be more specific, alginate is a biodegradable and biocompatible copolymer containing $\beta$-D-mannuronic acid $(M)$ and $\alpha$-L-guluronic acid $(G)$. It has been reported that the $G$ blocks contribute mainly to the gelation of alginate because when divalent cations (e.g., $\mathrm{Ca}^{2+}$ ) are introduced to an alginate solution, the $\mathrm{G}$ blocks in the alginate backbone form an ionic inter-chain bridge with the cations [46]. Moreover, the alginate hydrogel has a higher mechanical property than that of other biopolymers and as such is a suitable material for tissue regeneration. In addition, alginate-agarose [47], collagen-terpolymer [48], and arginyl-glycyl-aspartic acid (RGD)-modified alginate microcapsules [49] have been used to encapsulate cells with the electrostatic droplet extrusion technique.

Using this technology, Yao et al. produced alginate microspheres for rat adipose-derived stem cells (rADSCs) [50]. The rADSC-laden microspheres were formed by dropping the cell-suspended alginate solution into a calcium chloride solution. The authors considered four parameters such as voltage, electrode distance, push speed, and an inner diameter of the needle for the encapsulation and transplantation. They found that the critical factor affecting the microencapsulation was the electrode distance, that is the distance between the needle point and the copper sheet. Furthermore, it was shown that increasing the flow rate enhanced the production efficiency. In another study group, Moyer et al. developed humanADSC (hADSC)-laden microbeads for efficient delivery into the body by percutaneous injection [51] They encapsulated hADSCs in alginate microbeads using an electrostatic droplet generator and confirmed that smaller beads could be manufactured by increasing the electrical potential to $7 \mathrm{kV}$ and decreasing the flow rate to $<5 \mathrm{~mL} / \mathrm{h}$. They proved that at 3 months after percutaneous injection of the encapsulated hADSCs, stable protection of the cells during injection and in the body had been achieved.

\section{Microfluidic-based cell encapsulation}

Microfluidics is a technology based on the manipulation of a fluid in a microscopic environment, such as a 
microchannel [52]. It involves a variety of microfabrication processes and presents a promising approach toward the rapid and high-throughput containment of cells in microgels $[53,54]$. The advantages of this technology are that it enables precise environmental control, uniform size control with low shear stress, and device structure control according to various encapsulation conditions [55]. These microfluidic systems for cell encapsulation can be categorized into two major types: droplets and microfibers (Fig. 2c).

\section{Microfluidic encapsulation in droplets}

The microfluidic flow-focusing device is applied to cell encapsulation with various junction types. To control the generation of droplets, $\mathrm{T}$-junction and flow-focusing methods can be applied according to the channel geometry [56]. T-junction is coaxial capillary, and micro-nozzle cross-flow system and the size of the orifice of the T-junction greatly affect the size of the droplets formed. In the T-junction method, the main channel of the continuous phase and the inlet channel of the dispersed phase intersect perpendicularly with each other. The two phases form a contact at the junction with continuously flowing fluid in the main channel, and the tip of the dispersed phase enters the main channel. The size of the droplet is changed by controlling the flow rate or channel width, or by varying the relative viscosity [56-58]. In the flow-focusing method, the dispersion and continuous phases are allowed to pass through a narrow region of the microfluidic device. To better control and stabilize the droplets, symmetric shearing is used to place the continuous phase on the dispersed phase. The size of droplets can be reduced by increasing the speed of the fluid in the continuous phase [54, 58, 59]. In hydrogel solutions, cells are generally encapsulated by gelation of the cell suspension to form a coagulated matrix. The gelation depends on the encapsulating material (e.g., gelatin, agarose, alginate, and chitosan) and the cell-laden hydrogel droplets horizontally distributed to the dispersed phase.

Li et al. demonstrated that human bone marrow-derived MSCs (hBMSCs) encapsulated in protein-based microgels can be a therapeutic candidate for the longterm maintenance of articular cartilage regeneration under biocompatible microfluidic processing [60]. Zhao et al. reported a process that utilized this technology to facilitate bone regeneration with minimum invasion [61]. To generate injectable osteogenic tissue constructs, growth factors and rat BMSCs (rBMSCs) were entrapped in photocrosslinkable methacrylated gelatin (GelMA) microspheres. As a result, rBMSCs encapsulated in GelMA microspheres showed enhanced osteogenesis in vitro and in vivo.

\section{Microfluidic encapsulation in microfibers}

Microfluidic encapsulation in microfibers is defined as the formation of fibers within a microchannel using the coaxial flow of the initiating polymer and crosslinker [62]. Microfluidic fibers can be formed with various polymers, including gelatin-hydroxyphenylpropionic acid, alginate, chitosan, gelatin, and poly (lactic-co-glycolic acid) (PLGA). Microfluidic spinning is the proper technology for cell encapsulation because the fibers can be continuously produced and cover the cells without the need for a high voltage or temperature [63]. In microfluidics, PDMS-based and glass-based microfluidic chips are mainly used. These types of devices are easily extruded using similar materials and methods [63, 64]. Liu et al. reported mouse BMSC encapsulated alginate microfibers using microfluidic technology for vascular grafts [65]. The generated microfibers were controlled by the different flow rates and the diameters of a capillary glass tube.

\section{Bioprinting}

Bioprinting is an emerging technology for tissue regeneration because of its advantages, such as precise control of the cell density, high-resolution cell deposition, controllable scale, and cost-efficiency. The ultimate goal of bioprinting is the production of a living organ on a larger scale for transplantation which is required for many patients. Furthermore, the printed tissue becomes a possible tool for studying cell-cell and cell-matrix interactions in microenvironments by mimicking the 3D extracellular matrix (ECM). The basic concept of this technology is the layered deposition of cell-laden building blocks or cell aggregates using several types of rapid prototyping. There are three primary technologies, namely, inkjet bioprinting, laser-assisted bioprinting, and extrusion bioprinting that each with different processes and benefits (Fig. 2d).

\section{Inkjet bioprinting}

Inkjet bioprinting was the first technology of bioprinting and has a similar concept as conventional inkjet printing because it uses a cell-bearing pre-polymer solution (called a bioink solution) for ink cartridge dispensing [66]. The bioink is squeezed to produce bioink droplets through stimulation of the printer heads by a thermal piezoelectric activator [67]. Despite its low cost and high-throughput production of the parallel cell arrays, it is limited as a proper technology for tissue regeneration because it can only generate $2 \mathrm{D}$ tissue structure. Moreover, the disadvantages of nozzle clogging when used with high cell densities, non-uniform droplet size, lack of structural integrity between droplets, and the possibility of cell exposure to high heating temperature or 
mechanical stress are substantial challenges of this technology [68].

Although inkjet bioprinting fabricates a 2D structure, the attempt to generate 3D tissue constructs through a layer-by-layer method has been widely studied by many research groups. Gao et al. developed a highly mechanical bone and cartilage using inkjet printing with hMSCs [69]. They generated a bioprinted PEG-GelMA composite scaffold layer by layer to introduce a 3D structure for embedding hMSCs. They confirmed the osteogenesis and chondrogenesis of the hMSCs for 21 days, with a high compressive modulus ranging from 1 to $2 \mathrm{MPa}$. Another research group studied the differentiation ability of hMSCs in hydrogel blends of type 1 collagen- and chitosan-agarose that were printed by inkjet bioprinting [70]. The single drops of hydrogel were dispensed on top of one another to form a solid column. The hMSCs showed differentiation tendency toward osteogenic and adipogenic lineages, confirming that an anisotropic soft collagen-enriched 3D matrix was suitable for adipogenic differentiation, whereas an agarose-enriched matrix induced osteogenic differentiation. Therefore, these results showed that a 3D matrix printed by inkjet bioprinting was suitable for guiding MSC differentiation fates, and different types of tissue can be realized through control of the matrix stiffness.

\section{Extrusion bioprinting}

The most common type of 3D bioprinting is extrusion bioprinting, which was developed from the inkjet bioprinting technology. It involves extrusion printers, such as pneumatic and mechanical (piston or screw) dispensing systems, to extrude bioink droplets sequentially by forming cylindrical lines under a steady force. The major advantage of extrusion bioprinting is the ability to dispense bioinks with high cell density, which is essential for forming 3D tissue-derived organs [71]. Furthermore, since a wide range of viscous materials can be used, the selection of a variety of materials to encapsulate the cells is possible. Extrusion bioprinting is also able to produce multicellular spheroids for forming self-assembled tissue and organ constructs [72].

Using a customized microextrusion bioprinter, Du et al. fabricated a 3D bioprinted structure of rBMSC-laden GelMA scaffolds in the micrometer scale with a collagen-binding domain [73]. They confirmed the high cell viability $(>90 \%)$ and osteogenic differentiation of BMSCs for 14 days in the osteogenic medium by evaluating the gene expression of osteogenic markers, such as alkaline phosphatase (ALP), bone sialoprotein, osteocalcin $(\mathrm{OCN})$, and collagen type I. Another study group Levato et al. also established bone constructs from MSC-laden poly(lactic acid) microcarriers encapsulated in a GelMA-based hydrogel through extrusion bioprinting [74]. However, there is an obstacle of decreasing cell viability because of the extrusion pressure and the small diameter of the nozzle [75]. Therefore, enhancement of the cell viability and maintenance of the cell function in bioprinting composites are critical challenges for extrusion bioprinting technology.

\section{Laser-assisted bioprinting}

Laser-assisted bioprinting, which is based on laser-induced transfer, consists mainly of three components: a pulsed laser source, a donor layer, and a receiving substrate [76]. The donor layer is composed of an energy-absorbing layer (e.g., gold or titanium) on the top and a layer of mixed bioink solution (e.g., hydrogel and/or cells) on the bottom. A high-pressure bubble is formed at the interface of the bioink layer after the energy-absorbing layer is stimulated by focused laser pulses which evaporate donor layer part, and then the cell-containing solution is propelled to the receiving substrate [77]. The advantage of this technology is the high cell viability achieved as a result of the low mechanical stress on the cells due to the non-direct method between the bioink and dispenser. Furthermore, it is possible to deposit highly viscous materials with the high cell density concentrated bioink [78], and the bioprinter is able to use various types of bioink.

Gaebel et al. used modified laser-assisted bioprinting to develop a polyester urethane urea cardiac patch seeded with hBMSCs and HUVECs in a controlled pattern for cardiac regeneration [79]. They demonstrated that the co-printing of hBMSCs and HUVECs in the cardiac patch enhanced both the angiogenesis and the functional neo-vasculature that improves the functionality of an infarcted heart after transplantation. In another study group, Gruene et al. generated porcine BMSC-embedded 3D constructs by laser-induced forward transfer to confirm the viability and functionality of cells and their differentiation into bone and cartilage phenotypic cells [80]. They verified that laser-assisted bioprinting was capable of printing with a high cell density, which is essential for 3D tissue formation, and maintained cell viability during the printing process. Moreover, the MSC differentiation ability was observed from the expression of the osteogenic markers OCN and ALP and the chondrogenic markers collagen type II and aggrecan.

\section{Applications of cell encapsulation as regenerative medicine}

Cell encapsulation technologies provide a biomimetic 3D environment for MSCs to maintain their viability and functionality, resulting in their differentiation into many types of tissue. The spatiotemporal 3D environment affects MSC fate by matrix composition, substrate stiffness, porosity, and substrate structure. The different 3D environments influence integrin interaction and 
clustering between the MSCs and matrix which have cell adhesion and proliferation. These affect the signaling of the cell, that is transduced to the nucleus to regulate gene expression and consequently to alter the cell phenotype [81]. Therefore, tissue regeneration requires various environments depending on a tissue type, because of their distinct ECM parameters, respectively. In addition, biomechanical stimuli are not enough to enhance MSC differentiation, so the combination with biochemical components such as growth factors including BMP-2, TGF- $\beta 1$, VEGF, and FGF is critical [82]. 3D encapsulation technologies can provide physicochemical effects on MSCs by encapsulating both MSCs and growth factors. Thus, MSC encapsulation technologies that can provide diverse shapes, sizes, and matrix compositions with biochemical cues must be optimized depending on a targeted tissue. Among the various types of tissue, cartilage and bone are representatives of well-studied hard tissues. Moreover, the skin is a normal soft tissue that has been extensively studied. Blood vessel regeneration is also an important consideration because it is an essential requirement for all tissue regenerations. In this section, we will discuss the use of the MSC encapsulation technologies described above for the regeneration of these four types of tissue.

\section{Cartilage}

Injured cartilage is one of the most difficult tissues to regenerate because it is one of the avascular tissues with a limited supply of oxygen and nutrients. As a conventional treatment, autologous chondrocyte cell therapy has been widely applied, but it has drawbacks, such as its complexity, loss of cell functionality, and incomplete healing. Therefore, the method of MSC delivery to the defective site to induce differentiation toward chondrocytes is an emerging therapy for cartilage regeneration. Many research groups have examined various types of 3D environment scaffolds for delivering MSCs and inducing chondrogenesis. Peter et al. used extrusion bioprinting to encapsulate hBMSCs and human nasal chondrocytes creating human cartilage in vivo (Fig. 3A) [83]. Encapsulated hBMSCs enhanced the proliferation of chondrocytes and the formation of cartilage clusters. In addition, using a microfluidic device, Alireza et al. established a co-delivery system of TGF- $\beta 1$ and human dental MSCs (hDMSCs) in RGD-coupled alginate microspheres (Fig. 3B) [84]. In their study, the hDMSCs $\left(2 \times 10^{6} / \mathrm{ml}\right.$ in alginate $)$ differentiated into chondrocytes upon the presentation of TGF- $\beta 1$ as an inductive signal. The alginate microsphere-using microfluidic device was simple and maintained MSC viability and chondrogenic differentiation properly.

\section{Bone}

The implantation of a cell-laden 3D scaffold is important for the induction of osteogenesis in MSCs and the reconstruction of bone tissue. Leslie et al. encapsulated rADSCs in alginate and alginate-lyase combination
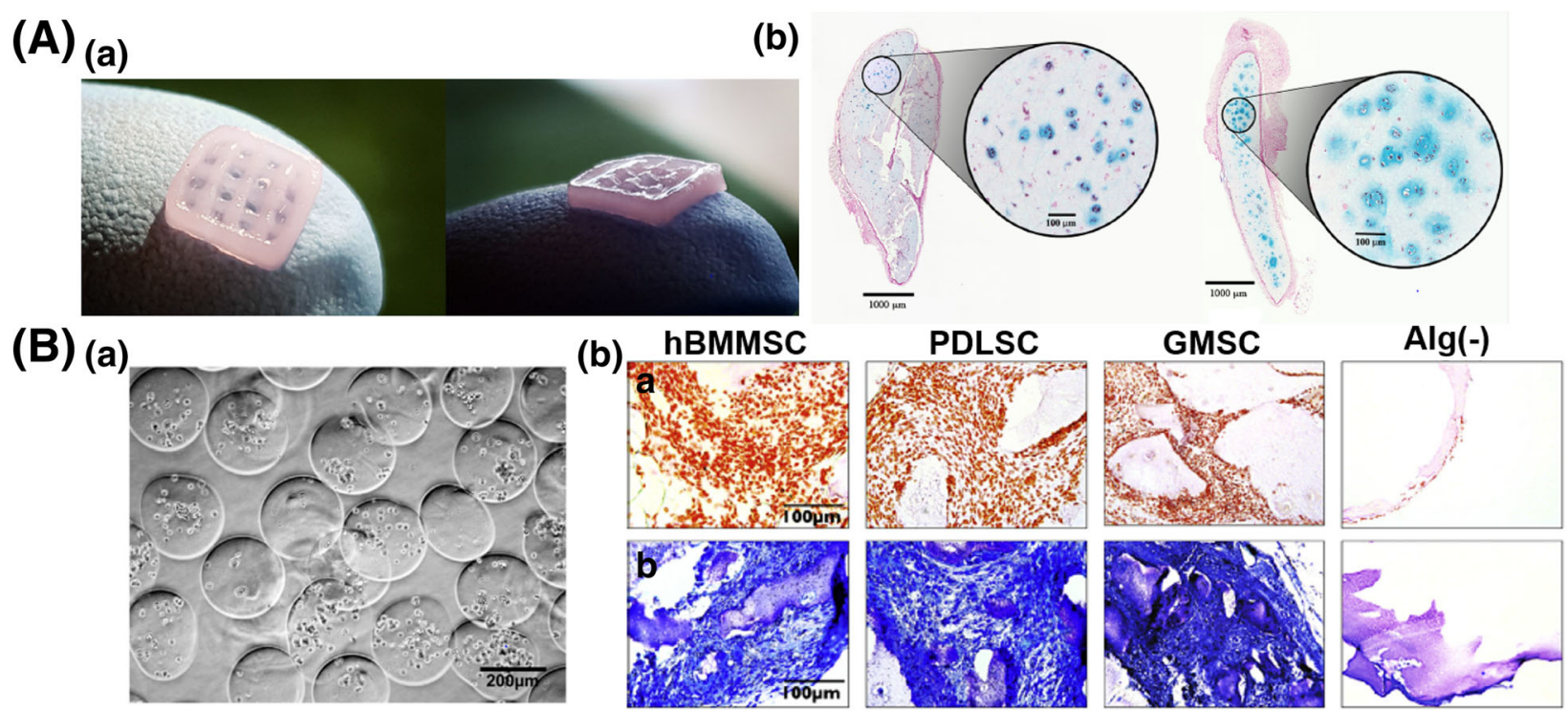

Fig. 3 Application of MSC encapsulation for cartilage regeneration. A (a) Cell-encapsulated nanofibrillated cellulose bioprinting gel. (b) Chondrocyte proliferation in 3D-bioprinted scaffold with hNCs and hBMSCs at day 30 (left) and day 60 (right) after subcutaneous implantation. Reproduced with permission from Reference [83]. Copyright 2017 PLOS. B (a) The periodontal ligament stem cells (PDLSCs), gingival mesenchymal stem cells (GMSCs), and hBMSC-encapsulated RGD-coupled alginate microbeads with TGF- $\beta 1$ by microfluidic device. (b) MSC-encapsulated microbeads stained safranin-O and toluidine blue that indicates proteoglycans, significantly. Reproduced with permission from Reference [84]. Copyright 2013 Elsevier 
hydrogel microbeads $(<200 \mu \mathrm{m})$ at a concentration of $25 \times 10^{6}$ cells $/ \mathrm{ml}$ using an electrostatic droplet generator (Fig. 4A) [85]. They controlled the degradation rate via the ratio of alginate-lyase to alginate for maintaining rADSCs viability in the injured site. The rADSCs released from the alginate-lyase microbeads were still viable after 12 days, and they released a high level of bone morphogenetic protein 2, VEGF-A, and FGF2, which are factors that stimulate bone regeneration. In another study group, Daniela et al. encapsulated hBMSCs in 3D agarose-collagen scaffold using inkjet bioprinting [86]. They confirmed that agarose is important to increase bioprinting contour accuracy, and collagen is crucial to enhance hBMSC proliferation resulting in osteogenic differentiation. As a result, high collagen concentration of scaffold was effective for bone regeneration. Chan et al. studied assembled cell spheroids by application of the microfluidic-based water-in-oil-in-water double-emulsion method [87]. The aggregated hBMSCs formed spheroids in the alginate and RGD-modified alginate droplets using $8 \times 10^{6}$ cells $/ \mathrm{ml}$. Furthermore, the hBMSC spheroids in the RGD-modified alginate showed enhanced osteogenic differentiation after 7 days in culture. The successful bone regeneration was clarified by alizarin red staining and an increase in ALP activity (Fig. 4B).

\section{Skin}

There has been a lot of research to reconstruct damaged skin, which covers most of the human body. Generally, burned tissue and chronic wounds have been successfully treated with scaffold-based tissue constructs [88]. Kim et al. introduced a skin-derived ECM bioink to fabricate a 3D thickness skin construct by bioprinting [89]. They made a 3D-printed skin patch with hADSCs and endothelial progenitor cells for wound healing. In vivo results demonstrated that the hADSCs enhanced wound healing, re-epithelialization, and the formation of new blood vessels that realize skin regeneration using $6 \times 10^{6}$ cells $/ \mathrm{ml}$ in media (Fig. 5A). Skardal et al. also used bioprinting technology to form full-thickness skin tissue on mice wounds [90]. hBMSCs and human amniotic fluid MSCs (hAFMSCs) that were suspended separately in a fibrin-collagen gel were printed over the wound site of mice. The hBMSC- and hAFMSC $\left(5 \times 10^{6}\right.$ cells/ scaffold)-encapsulated scaffolds accelerated wound
(A)
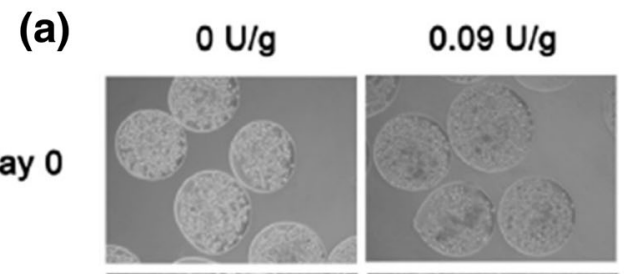

Day 12
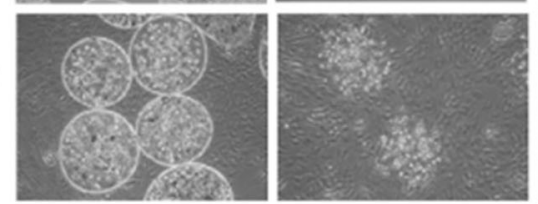

(a)

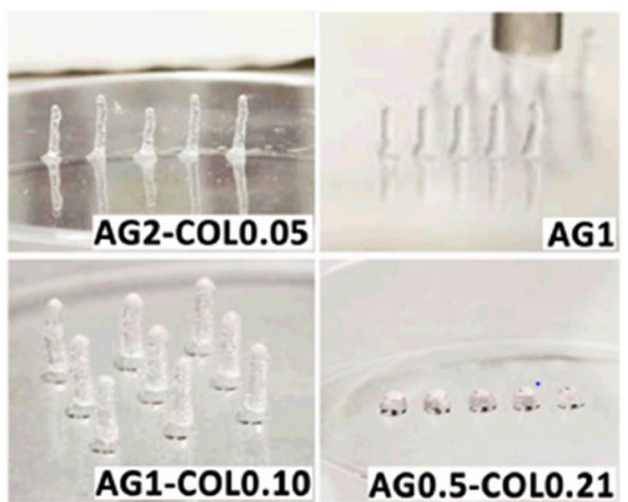

$0.13 \mathrm{U} / \mathrm{g}$
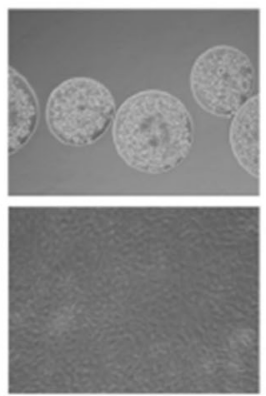

(B)

$$
\text { (a) }
$$

AG1-COL0.10

(b)

$0.18 \mathrm{U} / \mathrm{g}$
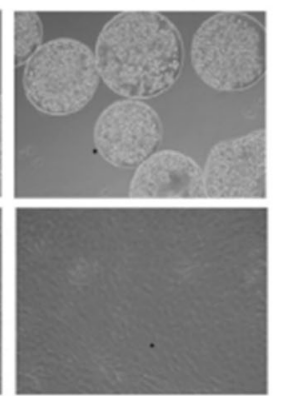

(b)

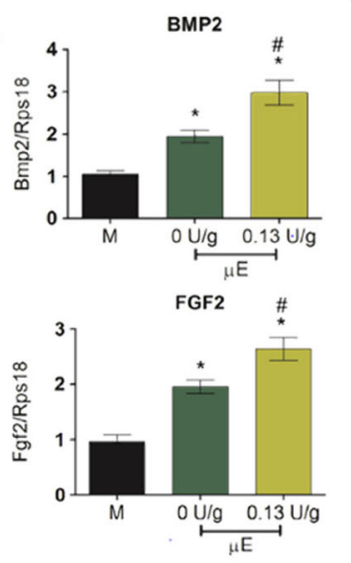

Fig. 4 Effective MSCs delivery for bone regeneration. A (a) Release of ADSCs from alginate microbeads with different concentration of alginatelyase by electrostatic droplet extrusion. (b) ADSC-encapsulated alginate-lyase microbeads revealed high expression of BMP-2 and FGF-2 that regulates bone regeneration. Reproduced with permission from Reference [85]. Copyright 2013 Elsevier. B (a) Printed agarose-collagen 3D columns and rings using inkjet bioprinting. (b) Alizarin red staining for hBMSC-loaded agarose-collagen hydrogel scaffold. Reproduced with permission from Reference [86]. Copyright 2016 John Wiley and Sons 


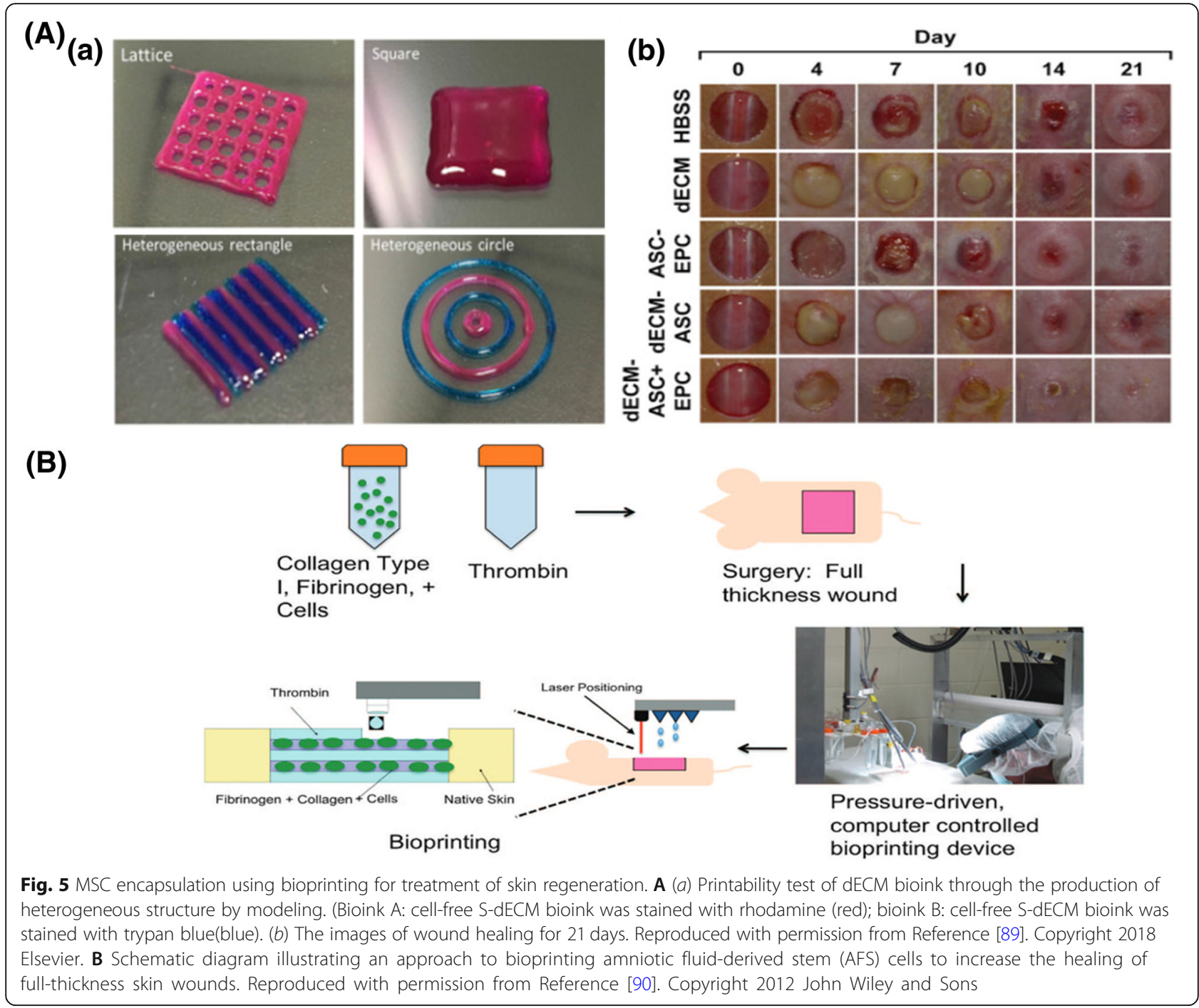

closure and re-epithelialization more significantly than did a cell-free fibrin-collagen scaffold. They concluded that growth factors secreted by hAFMSCs had induced angiogenesis and wound closure at the injured site (Fig. 5B).

\section{Blood vessel}

The reconstruction of blood vessels plays a key role in tissue regeneration because they supply oxygen and nutrients to tissues. As the source for regenerating blood vessels, MSCs are good candidates considering their unique antithrombogenic properties, immune response, and multipotency to differentiate into vascular phenotypes. Trkov et al. emphasized that unraveling the mechanism of blood vessel formation would offer therapeutic solutions because there are many limitations in oxygen and nutrient supply [36]. HUVEC- and hBMSC-encapsulated hydrogels were localized for each channel using microfluidic patterning $\left(10^{6}\right.$ cells/100 $\mu$ in PBS). The authors used a simple and robust mold to study communication within the cells of relevance for vascularized tissue engineering (Fig. 6A). Liu et al. investigated small diameter of vascular grafts through microfiber using microfluidic device. Encapsulated mouse BMSCs proliferated in the microfibers with VEGF and fibroblast growth factor (FGF) showed stable vascular regeneration (Fig. 6B) [65]. Jeon et al. described a number of factors related to vessel development, and the non-endothelial cell-specific growth factors, such as the proteins of the TGF family that are also required for angiogenesis [91]. They demonstrated that two endothelial cell-related molecules, angiopoietin and TGF- $\beta 1$, released from encapsulated hBMSCs $\left(6 \times 10^{6}\right.$ cells $/ \mathrm{ml}$ in hydrogel suspension) using a microfluidic device, played an important role in angiogenesis.

\section{Conclusion}

Tissue regeneration is one of the most prominent and vital approaches in diverse biomedical applications. 


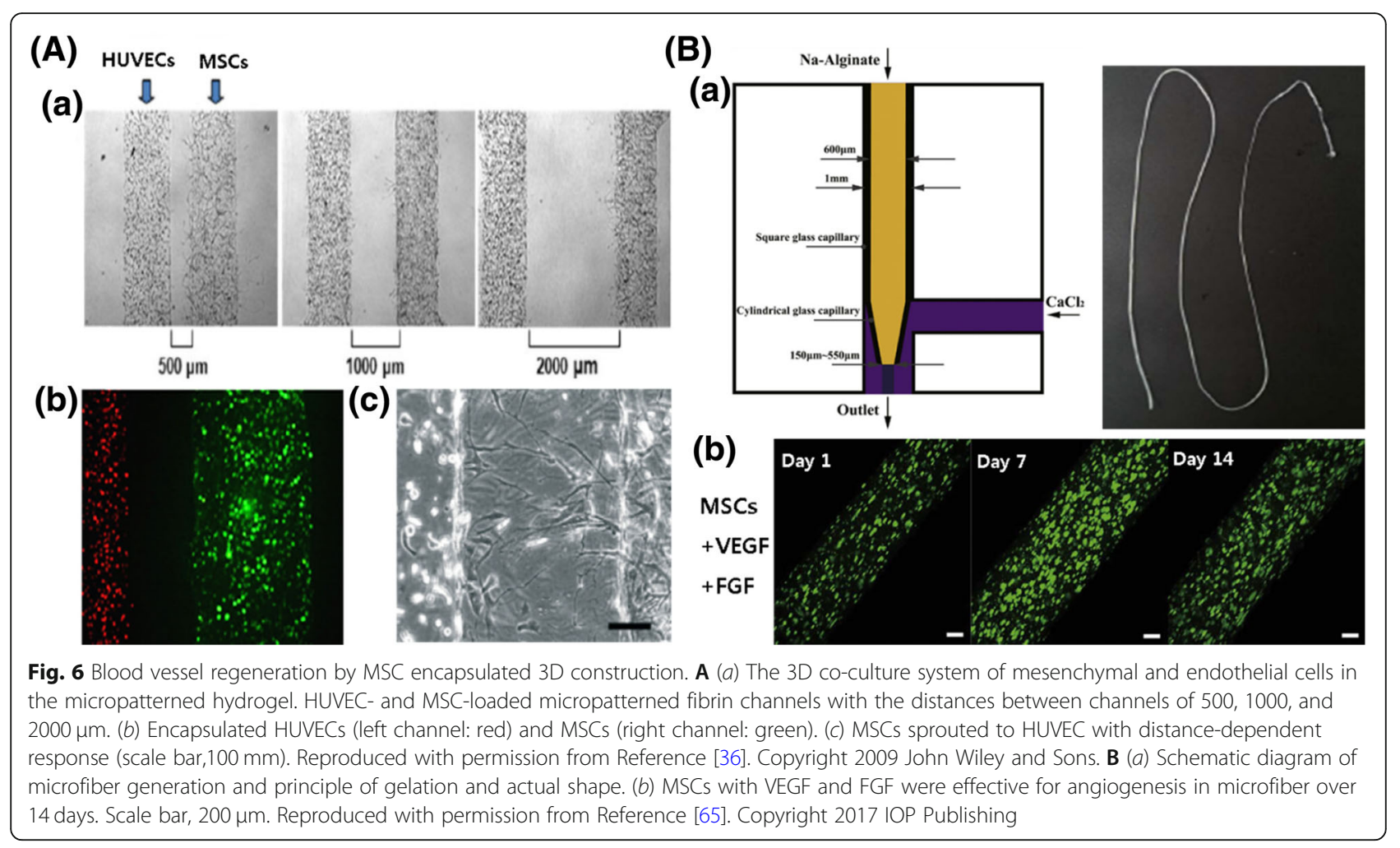

MSCs, which are known to have a lot of potential and play an increasingly leading role in tissue engineering and regenerative medicine, have only recently been applied as a biomedicine. In this review, we have investigated various MSC encapsulation technologies and their applications in tissue regeneration. For clinical applications, we need to use a variety of techniques, but among them, we have looked at four technologies: micromolding, electrostatic droplet extrusion, microfluidics, and bioprinting. The advantages of MSC encapsulation technologies are improvement of MSC viability, proliferation, differentiation capacity, and protection of MSCs from the immune system in the body. These technologies which are composed using 3D environment structure can provide safe delivery of MSCs into a specific site of defection, which can provide long-term cell-based therapy for tissue regeneration. Therefore, mass production of MSCs and scaled-up matrix are critical challenges that are to be considered for clinical application of the tissue regeneration. In other words, cost, time, and labor efficiency of cell encapsulation and transplantation are challenges. Additional challenge is to consider the encapsulation biomaterial as the immune response to the implanted MSC-encapsulated matrix. Thus, the simple and easy technique to encapsulate MSCs and a combination of biocompatible materials must be improved for effective tissue regeneration.
Previous tissue engineering methods using MSC encapsulation have used each technology of micromolding, electrostatic droplet extrusion, microfluidics, and bioprinting individually. However, we need to combine these technologies to overcome the limitations of each and thereby increase their advantages. Besides this, although MSCs are considered to be an attractive cell source owing to their multipotency, it is difficult to ignore their possible differentiation into an abnormal tissue. Through a preliminary study of the differentiation of MSCs and their effects, diseases caused by unexpected differentiation can be prevented and treated. Therefore, MSC encapsulation technology has the potential to be utilized infinitely in therapeutic medicine by suppressing the abnormal differentiation and side effects of MSCs. In conclusion, MSC encapsulation is a very promising technology for use in tissue engineering and regenerative medicine applications, depending on the occasion and purpose.

\section{Abbreviations}

2D: Two-dimensional; 3D: Three-dimensional; ALP: Alkaline phosphatase; ECM: Extracellular matrix; FGF: Fibroblast growth factor; G: a-L-Guluronic acid; GeIMA: Methacrylated gelatin; hADSCs: Human adipose-derived stem cells; hAFMSCs: Human amniotic fluid MSCs; hBMSCs: Human bone marrow-derived MSCs; hDMSCs: Human dental MSCs; hNCs: Human nasal chondrocytes; HSPCs: Hematopoietic stem/progenitor cells; HUVECs: Human umbilical vein endothelial cells; IL-2: Interleukin-2; IL-8: Interleukin-8; M: Containing $\beta$-Dmannuronic acid; MCP-1: Monocyte chemotactic protein-1; MSC: Mesenchymal stem cell; OCN: Osteocalcin; PDMS: Polydimethylsiloxane; PLGA: Poly (lactic-coglycolic acid; rADSCs: Rat adipose-derived stem cells; rBMSCs: Rat bone marrow- 
derived MSCS; RGD: Arginyl-glycyl-aspartic acid; SDF-1: Stromal-derived factor-1; TGF- $\beta$ : Transforming growth factor-beta; VEGF: Vascular endothelial growth factor

\section{Acknowledgements}

Not applicable

\section{Funding}

This work was supported by the National Research Foundation of Korea (NRF) funded by the Ministry of Science, ICT \& Future Planning (2016M3A9B4919711, 2017M3A9E9073680, and 2017M3A7B4049850; K Lee, 2018R1C1B6002333; M. H. Park). This work was also supported by NRF (National Research Foundation of Korea) Grant funded by the Korean Government (NRF-2017-Global Ph.D. Fellowship Program) and a grant from the Korea Health Technology R\&D Project through the Korea Health Industry Development Institute (KHIDI), funded by the Ministry of Health and Welfare, Republic of Korea (grant number: HI15C1744; W. G. Koh).

\section{Availability of data and materials}

The sources for the information discussed in this review can be obtained from the papers cited in the references.

\section{Authors' contributions}

HK and CB conceived and wrote the manuscript. YMK and WGK revised the paper. $\mathrm{KL}$ and MHP reviewed and edited the manuscript. All authors read and approved the final manuscript.

\section{Ethics approval and consent to participate}

Not applicable

\section{Consent for publication}

Not applicable

\section{Competing interests}

The authors declare that they have no competing interests.

\section{Publisher's Note}

Springer Nature remains neutral with regard to jurisdictional claims in published maps and institutional affiliations.

\section{Author details}

'Program in Nanoscience and Technology, Graduate School of Convergence Science and Technology, Seoul National University, Seoul, Republic of Korea. ${ }^{2}$ Department of Chemical and Biomolecular Engineering, Yonsei University, Seoul, Republic of Korea. ${ }^{3}$ Advanced Institutes of Convergence Technology, Suwon, Republic of Korea. ${ }^{4}$ Center for Convergence Bioceramic Materials, Korea Institute of Ceramic Engineering and Technology, Cheongju, Republic of Korea.

\section{Published online: 07 February 2019}

\section{References}

1. Liu S, Zhou J, Zhang X, Liu Y, Chen J, Hu B, et al. Strategies to optimize adult stem cell therapy for tissue regeneration. Int J Mol Sci. 2016;17(6):982.

2. Kim HJ, Park JS. Usage of human mesenchymal stem cells in cell-based therapy: advantages and disadvantages. Dev Reprod. 2017;21(1):1-10.

3. Kern S, Eichler H, Stoeve J, Kluter H, Bieback K. Comparative analysis of mesenchymal stem cells from bone marrow, umbilical cord blood, or adipose tissue. Stem Cells. 2006:24(5):1294-301.

4. Chen Q, Shou P, Zheng C, Jiang M, Cao G, Yang Q, et al. Fate decision of mesenchymal stem cells: adipocytes or osteoblasts? Cell Death Differ. 2016; 23(7):1128-39.

5. Caplan Al. Mesenchymal stem cells. J Orthop Res. 1991;9(5):641-50.

6. Park CW, Kim KS, Bae S, Son HK, Myung PK, Hong HJ, et al. Cytokine secretion profiling of human mesenchymal stem cells by antibody array. Int J Stem Cells. 2009:2(1):59-68.

7. Kyurkchiev D, Bochev I, Ivanova-Todorova E, Mourdjeva M, Oreshkova T, Belemezova K, et al. Secretion of immunoregulatory cytokines by mesenchymal stem cells. World J Stem Cells. 2014;6(5):552-70.

8. Caplan Al, Dennis JE. Mesenchymal stem cells as trophic mediators. J Cell Biochem. 2006;98(5):1076-84.
9. Baker BM, Chen CS. Deconstructing the third dimension: how 3D culture microenvironments alter cellular cues. J Cell Sci. 2012:125(Pt 13):3015-24.

10. Cukierman E, Pankov R, Stevens DR, Yamada KM. Taking cell-matrix adhesions to the third dimension. Science. 2001;294(5547):1708-12.

11. Machado CB, Ventura JM, Lemos AF, Ferreira JM, Leite MF, Goes AM. 3D chitosan-gelatin-chondroitin porous scaffold improves osteogenic differentiation of mesenchymal stem cells. Biomed Mater. 2007;2(2):124-31.

12. Papadimitropoulos A, Piccinini E, Brachat S, Braccini A, Wendt D, Barbero A, et al. Expansion of human mesenchymal stromal cells from fresh bone marrow in a 3D scaffold-based system under direct perfusion. PLoS One. 2014;9(7):e102359.

13. Bao J, Wu Q, Wang Y, Li Y, Li L, Chen F, et al. Enhanced hepatic differentiation of rat bone marrow-derived mesenchymal stem cells in spheroidal aggregate culture on a decellularized liver scaffold. Int J Mol Med. 2016;38(2):457-65.

14. Wu Q, Tang J, Li Y, Li L, Wang Y, Bao J, et al. Hepatic differentiation of mouse bone marrow-derived mesenchymal stem cells using a novel 3D culture system. Mol Med Rep. 2017;16(6):9473-9.

15. Kook YM, Kim H, Kim S, Heo CY, Park MH, Lee K, et al. Promotion of vascular morphogenesis of endothelial cells co-cultured with human adiposederived mesenchymal stem cells using polycaprolactone/gelatin nanofibrous scaffolds. Nanomaterials (Basel). 2018:8(2):117.

16. Huang $X$, Zhu B, Wang $X$, Xiao R, Wang C. Three-dimensional co-culture of mesenchymal stromal cells and differentiated osteoblasts on human bio-derived bone scaffolds supports active multi-lineage hematopoiesis in vitro: functional implication of the biomimetic HSC niche. Int J Mol Med. 2016;38(4):1141-51.

17. Futrega K, Atkinson K, Lott WB, Doran MR. Spheroid coculture of hematopoietic stem/progenitor cells and monolayer expanded mesenchymal stem/stromal cells in polydimethylsiloxane microwells modestly improves in vitro hematopoietic stem/progenitor cell expansion. Tissue Eng Part C Methods. 2017;23(4):200-18.

18. Pereira RC, Gentili C, Cancedda R, Azevedo HS, Reis RL. Encapsulation of human articular chondrocytes into 3D hydrogel: phenotype and genotype characterization. Methods Mol Biol. 2011;695:167-81.

19. Moshaverinia A, Xu XT, Chen C, Ansari S, Zadeh HH, Snead ML, et al. Application of stem cells derived from the periodontal ligament or gingival tissue sources for tendon tissue regeneration. Biomaterials. 2014:35(9):2642-50.

20. Kook YM, Kang YM, Moon SH, Koh WG. Bi-compartmental 3D scaffolds for the co-culture of intervertebral disk cells and mesenchymal stem cells. J Ind Eng Chem. 2016;38:113-22.

21. Huebsch N, Lippens E, Lee K, Mehta M, Koshy ST, Darnell MC, et al. Matrix elasticity of void-forming hydrogels controls transplanted-stem-cellmediated bone formation. Nat Mater. 2015;14(12):1269-77.

22. Park JS, Shim MS, Shim SH, Yang HN, Jeon SY, Woo DG, et al. Chondrogenic potential of stem cells derived from amniotic fluid, adipose tissue, or bone marrow encapsulated in fibrin gels containing TGF-beta 3. Biomaterials. 2011;32(32):8139-49

23. Simian M, Bissell MJ. Organoids: a historical perspective of thinking in three dimensions. J Cell Biol. 2017;216(1):31-40.

24. TMS C. Semipermeable microcapsules. Science. 1964;146(364):524-5.

25. Batorsky A, Liao JH, Lund AW, Plopper GE, Stegemann JP. Encapsulation of adult human mesenchymal stem cells within collagen-agarose microenvironments. Biotechnol Bioeng. 2005;92(4):492-500.

26. Tian YF, Devgun JM, Collier JH. Fibrillized peptide microgels for cell encapsulation and 3D cell culture. Soft Matter. 2011;7(13):6005-11.

27. Lim F, Sun AM. Microencapsulated islets as bioartificial endocrine pancreas. Science. 1980:210(4472):908-10.

28. Tatarkiewicz K. New membrane for cell encapsulation. Artif Organs. 1988: 12(5):446-8.

29. Li RH, Altreuter DH, Gentile FT. Transport characterization of hydrogel matrices for cell encapsulation. Biotechnol Bioeng. 1996:50(4):365-73.

30. Zielinski BA, Aebischer P. Chitosan as a matrix for mammalian-cell encapsulation. Biomaterials. 1994:15(13):1049-56.

31. Allen TD, Schor SL. The contraction of collagen matrices by dermal fibroblasts. J Ultrastruct Res. 1983:83(2):205-19.

32. Bessis N, Honiger J, Damotte D, Minty A, Fournier C, Fradelizi D, et al. Encapsulation in hollow fibres of xenogeneic cells engineered to secrete IL4 or IL-13 ameliorates murine collagen-induced arthritis (CIA). Clin Exp Immunol. 1999:117(2):376-82

33. Ashammakhi N, Ahadian S, Zengjie F, Suthiwanich K, Lorestani F, Orive G, et al. Advances and future perspectives in 4D bioprinting. Biotechnol J. 2018; 13:1800148. 
34. Khademhosseini A, Langer R. Microengineered hydrogels for tissue engineering. Biomaterials. 2007;28(34):5087-92.

35. McGuigan AP, Bruzewicz DA, Glavan A, Butte M, Whitesides GM. Cell encapsulation in sub-mm sized gel modules using replica molding. PLoS One. 2008;3(5):e2258

36. Trkov S, Eng G, Di Liddo R, Parnigotto PP, Vunjak-Novakovic G. Micropatterned three-dimensional hydrogel system to study human endothelial - mesenchymal stem cell interactions. J Tissue Eng Regen Med. 2010;4(3):205-15

37. Vorwald CE, Ho SS, Whitehead J, Leach JK. High-throughput formation of mesenchymal stem cell spheroids and entrapment in alginate hydrogels. Methods Mol Biol. 2018;1758:139-49.

38. Hamilton SK, Bloodworth NC, Massad CS, Hammoudi TM, Suri S, Yang PJ, et al. Development of 3D hydrogel culture systems with on-demand cell separation. Biotechnol J. 2013:8(4):485-95.

39. Selimovic S, Oh J, Bae H, Dokmeci M, Khademhosseini A. Microscale strategies for generating cell-encapsulating hydrogels. Polymers. 2012;4(3): 1554-79.

40. Kim E, Xia YN, Whitesides GM. Micromolding in capillaries: applications in materials science. J Am Chem Soc. 1996;118(24):5722-31.

41. Coutinho DF, Gomes ME, Neves NM, Reis RL. Development of micropatterned surfaces of poly(butylene succinate) by micromolding for guided tissue engineering. Acta Biomater. 2012;8(4):1490-7.

42. Bugarski B, Li QL, Goosen MFA, Poncelet D, Neufeld RJ, Vunjakg. Electrostatic droplet generation - mechanism of polymer droplet formation. AICHE J 1994:40(6):1026-1031.

43. Yao R, Zhang R, Luan J, Lin F. Alginate and alginate/gelatin microspheres for human adipose-derived stem cell encapsulation and differentiation. Biofabrication. 2012;4(2):025007.

44. Al-Hajry HA, Al-Maskry SA, Al-Kharousi LM, El-Mardi O, Shayya WH, Goosen MFA. Electrostatic encapsulation and growth of plant cell cultures in alginate. Biotechnol Prog. 1999;15(4):768-74

45. Poncelet D, Babak VG, Neufeld RJ, Goosen MFA, Burgarski B. Theory of electrostatic dispersion of polymer solutions in the production of microgel beads containing biocatalyst. Adv Colloid Interf Sci. 1999;79(2-3):213-28.

46. Andersen T, Auk-Emblem P, Dornish M. 3D cell culture in alginate hydrogels. Microarrays (Basel). 2015;4(2):133-61.

47. Orive G, Hernandez RM, Gascon AR, Igartua M, Pedraz JL. Survival of different cell lines in alginate-agarose microcapsules. Eur J Pharm Sci. 2003;18(1):23-30.

48. Zhou Y, Sun T, Chan M, Zhang J, Han Z, Wang X, et al. Scalable encapsulation of hepatocytes by electrostatic spraying. J Biotechnol. 2005; 117(1):99-109.

49. Yu JS, Du KT, Fang QZ, Gu YP, Mihardja SS, Sievers RE, et al. The use of human mesenchymal stem cells encapsulated in RGD modified alginate microspheres in the repair of myocardial infarction in the rat. Biomaterials. 2010;31(27):7012-20

50. Yao R, Zhang RJ, Wang XH. Design and evaluation of a cell microencapsulating device for cell assembly technology. J Bioact Compat Polym. 2009:24:48-62.

51. Moyer HR, Kinney RC, Singh KA, Williams JK, Schwartz Z, Boyan BD. Alginate microencapsulation technology for the percutaneous delivery of adiposederived stem cells. Ann Plast Surg. 2010;65(5):497-503.

52. Saltzman WM, Olbricht WL. Building drug delivery into tissue engineering Nat Rev Drug Discov. 2002;1(3):177-86.

53. Wu HW, Lin CC, Lee GB. Stem cells in microfluidics. Biomicrofluidics. 2011; 5(1):013401.

54. Velasco D, Tumarkin E, Kumacheva E. Microfluidic encapsulation of cells in polymer microgels. Small. 2012;8(11):1633-42.

55. Mazzitelli S, Capretto L, Quinci F, Piva R, Nastruzzi C. Preparation of cellencapsulation devices in confined microenvironment. Adv Drug Deliv Rev. 2013;65(11-12):1533-55.

56. Mazutis $L$, Gilbert J, Ung WL, Weitz DA, Griffiths AD, Heyman JA. Single-cell analysis and sorting using droplet-based microfluidics. Nat Protoc. 2013;8(5):870-91.

57. Collins DJ, Neild A, deMello A, Liu AQ, Ai Y. The Poisson distribution and beyond: methods for microfluidic droplet production and single cell encapsulation. Lab Chip. 2015;15(17):3439-59.

58. Teh SY, Lin R, Hung LH, Lee AP. Droplet microfluidics. Lab Chip. 2008;8(2): $198-220$.

59. Chabert M, Viovy JL. Microfluidic high-throughput encapsulation and hydrodynamic self-sorting of single cells. Proc Natl Acad Sci U S A. 2008; 105(9):3191-6.
60. Li FY, Truong VX, Thissen H, Frith JE, Forsythe JS. Microfluidic encapsulation of human mesenchymal stem cells for articular cartilage tissue regeneration. ACS Appl Mater Interfaces. 2017;9(10):8589-601.

61. Zhao X, Liu S, Yildirimer L, Zhao H, Ding RH, Wang HN, et al. Injectable stem cell-laden photocrosslinkable microspheres fabricated using microfluidics for rapid generation of osteogenic tissue constructs. Adv Funct Mater. 2016; 26(17):2809-19.

62. Tamayol A, Akbari M, Annabi N, Paul A, Khademhosseini A, Juncker D. Fiberbased tissue engineering: progress, challenges, and opportunities. Biotechnol Adv. 2013;31(5):669-87.

63. Steele JAM, Barron AE, Carmona E, Halle JP, Neufeld RJ. Encapsulation of protein microfiber networks supporting pancreatic islets. J Biomed Mater Res A. 2012:100a(12):3384-91.

64. Lee BR, Lee KH, Kang E, Kim DS, Lee SH. Microfluidic wet spinning of chitosan-alginate microfibers and encapsulation of HepG2 cells in fibers. Biomicrofluidics. 2011;5(2):022208

65. Liu MY, Zhou ZZ, Chai YC, Zhang S, Wu XM, Huang SP, et al. Synthesis of cell composite alginate microfibers by microfluidics with the application potential of small diameter vascular grafts. Biofabrication. 2017;9(2):025030.

66. Wilson WC Jr, Boland T. Cell and organ printing 1: protein and cell printers Anat Rec A Discov Mol Cell Evol Biol. 2003;272(2):491-6.

67. Xu T, Kincaid H, Atala A, Yoo JJ. High-throughput production of single-cell microparticles using an inkjet printing technology. J Manuf Sci Eng Trans Asme. 2008;130(2):021017.

68. Murphy SV, Atala A. 3D bioprinting of tissues and organs. Nat Biotechnol. 2014;32(8):773-85.

69. Gao GF, Schilling AF, Hubbell K, Yonezawa T, Truong D, Hong Y, et al. Improved properties of bone and cartilage tissue from 3D inkjet-bioprinted human mesenchymal stem cells by simultaneous deposition and photocrosslinking in PEG-GelMA. Biotechnol Lett. 2015;37(11):2349-55.

70. Duarte Campos DF, Blaeser A, Korsten A, Neuss S, Jakel J, Vogt M, et al. The stiffness and structure of three-dimensional printed hydrogels direct the differentiation of mesenchymal stromal cells toward adipogenic and osteogenic lineages. Tissue Eng Part A. 2015;21(3-4): 740-56

71. Chang CC, Boland ED, Williams SK, Hoying JB. Direct-write bioprinting threedimensional biohybrid systems for future regenerative therapies. J Biomed Mater Res B Appl Biomater. 2011:98(1):160-70.

72. Mironov V, Visconti RP, Kasyanov V, Forgacs G, Drake CJ, Markwald RR. Organ printing: tissue spheroids as building blocks. Biomaterials. 2009; 30(12):2164-74.

73. Du M, Chen B, Meng Q, Liu S, Zheng X, Zhang C, et al. 3D bioprinting of BMSC-laden methacrylamide gelatin scaffolds with CBD-BMP2-collagen microfibers. Biofabrication. 2015;7(4):044104.

74. Levato R, Visser J, Planell JA, Engel E, Malda J, Mateos-Timoneda MA. Biofabrication of tissue constructs by 3D bioprinting of cell-laden microcarriers. Biofabrication. 2014:6(3):035020.

75. Irvine SA, Venkatraman SS. Bioprinting and differentiation of stem cells. Molecules. 2016;21(9):1188.

76. Barron JA, Wu P, Ladouceur HD, Ringeisen BR. Biological laser printing: a novel technique for creating heterogeneous 3-dimensional cell patterns. Biomed Microdevices. 2004;6(2):139-47.

77. Mandrycky C, Wang Z, Kim K, Kim DH. 3D bioprinting for engineering complex tissues. Biotechnol Adv. 2016;34(4):422-34.

78. Guillotin B, Souquet A, Catros S, Duocastella M, Pippenger B, Bellance S, et al. Laser assisted bioprinting of engineered tissue with high cell density and microscale organization. Biomaterials. 2010;31(28):7250-6.

79. Gaebel R, Ma N, Liu J, Guan J, Koch L, Klopsch C, et al. Patterning human stem cells and endothelial cells with laser printing for cardiac regeneration. Biomaterials. 2011:32(35):9218-30.

80. Gruene M, Deiwick A, Koch L, Schlie S, Unger C, Hofmann N, et al. Laser printing of stem cells for biofabrication of scaffold-free autologous grafts. Tissue Eng Part C Methods. 2011;17(1):79-87.

81. Leach JK, Whitehead J. Materials-directed differentiation of mesenchymal stem cells for tissue engineering and regeneration. Acs Biomater Sci Eng. 2018:4(4):1115-27.

82. Meng $X$, Leslie $P$, Zhang $Y$, Dong J. Stem cells in a three-dimensional scaffold environment. Springerplus. 2014;3:80.

83. Apelgren P, Amoroso M, Lindahl A, Brantsing C, Rotter N, Gatenholm P, et al. Chondrocytes and stem cells in 3D-bioprinted structures create human cartilage in vivo. PLoS One. 2017;12(12):e0189428. 
84. Moshaverinia A, Xu X, Chen C, Akiyama K, Snead ML, Shi S. Dental mesenchymal stem cells encapsulated in an alginate hydrogel co-delivery microencapsulation system for cartilage regeneration. Acta Biomater. 2013;9(12):9343-50.

85. Leslie SK, Cohen DJ, Sedlaczek J, Pinsker EJ, Boyan BD, Schwartz Z Controlled release of rat adipose-derived stem cells from alginate microbeads. Biomaterials. 2013;34(33):8172-84

86. Duarte Campos DF, Blaeser A, Buellesbach K, Sen KS, Xun W, Tillmann W, et al. Bioprinting organotypic hydrogels with improved mesenchymal stem cell remodeling and mineralization properties for bone tissue engineering. Adv Healthc Mater. 2016:5(11):1336-45.

87. Chan HF, Zhang Y, Ho YP, Chiu YL, Jung Y, Leong KW. Rapid formation of multicellular spheroids in double-emulsion droplets with controllable microenvironment. Sci Rep. 2013;3:3462.

88. Priya SG, Jungvid $H$, Kumar A. Skin tissue engineering for tissue repair and regeneration. Tissue Eng Part B Rev. 2008;14(1):105-18.

89. Kim BS, Kwon YW, Kong JS, Park GT, Gao G, Han W, et al. 3D cell printing of in vitro stabilized skin model and in vivo pre-vascularized skin patch using tissue-specific extracellular matrix bioink: a step towards advanced skin tissue engineering. Biomaterials. 2018;168:38-53.

90. Skardal A, Mack D, Kapetanovic E, Atala A, Jackson JD, Yoo J, et al. Bioprinted amniotic fluid-derived stem cells accelerate healing of large skin wounds. Stem Cells Transl Med. 2012:1(11):792-802.

91. Jeon JS, Bersini S, Whisler JA, Chen MB, Dubini G, Charest JL, et al. Generation of 3D functional microvascular networks with human mesenchymal stem cells in microfluidic systems. Integr Biol. 2014;6(5):555-63.

92. Broers AN, Harper JME, Molzen WW. 250- $\AA$ linewidths with PMMA electron resist. Appl Phys Lett. 1978;33(5):392-4.

93. Xia YN, Kim E, Zhao XM, Rogers JA, Prentiss M, Whitesides GM. Complex optical surfaces formed by replica molding against elastomeric masters. Science. 1996;273(5273):347-9.

94. Xia YN, Kim E, Whitesides GM. Micromolding of polymers in capillaries: applications in microfabrication. Chem Mater. 1996;8(7):1558-67.

95. Nawab MA, Mason SG. The preparation of uniform emulsions by electrical dispersion. J Colloid Sci. 1958;13(2):179-87.

96. Goosen MFA, O'Shea GM, Gharapetian HM, Sun AM. Immobilization of living cells in biocompatible semipermeable microcapsules: biomedical and potential biochemical engineering applications. Polymers Med II. 1986;34: 235-46.

97. Li X, Liu T, Song K, Yao L, Ge D, Bao C, et al. Culture of neural stem cells in calcium alginate beads. Biotechnol Prog. 2006;22(6):1683-9.

98. Ding HF, Liu R, Li BG, Lou JR, Dai KR, Tang TT. Biologic effect and immunoisolating behavior of BMP-2 gene-transfected bone marrow-derived mesenchymal stem cells in APA microcapsules. Biochem Biophys Res Commun. 2007:362(4):923-7.

99. Smith L. Micromachined nozzles fabricated with a replicative method. Tech Digest MME. 1990;90:53-7.

100. Sugiura S, Oda T, Izumida Y, Aoyagi Y, Satake M, Ochiai A, et al. Size control of calcium alginate beads containing living cells using micro-nozzle array. Biomaterials. 2005;26(16):3327-31.

101. Zhang H, Tumarkin E, Peerani R, Nie Z, Sullan RMA, Walker GC, et al. Microfluidic production of biopolymer microcapsules with controlled morphology. J Am Chem Soc. 2006;128(37):12205-10.

102. Edd JF, Di Carlo D, Humphry KJ, Koster S, Irimia D, Weitz DA, et al. Controlled encapsulation of single-cells into monodisperse picolitre drops. Lab Chip. 2008;8(8):1262-4

103. Hull CW. The birth of 3D printing IRI achievement award address. Res Technol Manag. 2015;58(6):25-9.

104. Wang X, Ao Q, Tian X, Fan J, Wei Y, Hou W, et al. 3D bioprinting technologies for hard tissue and organ engineering. Materials (Basel). 2016; 9(10):802.

105. Schuurman W, Khristov V, Pot MW, van Weeren PR, Dhert WJ, Malda J. Bioprinting of hybrid tissue constructs with tailorable mechanical properties. Biofabrication. 2011;3(2):021001.

106. Gao B, Yang Q, Zhao X, Jin G, Ma Y, Xu F. 4D bioprinting for biomedical applications. Trends Biotechnol. 2016;34(9):746-56.

107. Zhu W, Cui HT, Boualam B, Masood F, Flynn E, Rao RD, et al. 3D bioprinting mesenchymal stem cell-laden construct with core-shell nanospheres for cartilage tissue engineering. Nanotechnology. 2018;29(18):185101. 